\title{
Chloroquine increases the anti-cancer activity of epirubicin in A549 lung cancer cells
}

\author{
AI-LING LIANG ${ }^{1,2^{*}}$, JING ZHANG $^{3 *}$, SHEN-LIN DU ${ }^{4}$, BIN ZHANG $^{2,5}$ \\ XUAN MA ${ }^{2,5}$, CUI-YUN WU ${ }^{3}$ and YONG-JUN LIU ${ }^{2,5}$

\begin{abstract}
${ }^{1}$ Department of Clinical Biochemistry; ${ }^{2}$ Guangdong Medical Molecular Diagnostic Key Laboratory, Guangdong Medical University, Dongguan, Guangdong 523808; ${ }^{3}$ The Clinical Laboratory of Shunde Hospital, Southern Medical University,

${ }^{5}$ Department of Biochemistry and Molecular Biology, Guangdong Medical University, Dongguan, Guangdong 523808, P.R. China
\end{abstract} \\ Foshan, Guangdong 528300; ${ }^{4}$ Blood Transfusion Department, Dongguan Tung Wah Hospital, Dongguan, Guangdong 523110;
}

Received September 7, 2018; Accepted October 22, 2019

DOI: 10.3892/ol.2020.11567

\begin{abstract}
The present study investigated whether the autophagy inhibitor chloroquine (CQ) can improve the sensitivity of the A549 lung cancer cell line to epirubicin (EPI). The Cell Counting Kit 8 (CCK8) assay was used to determine the EPI $\mathrm{IC}_{50}$ in $\mathrm{A} 549$ cells treated for $72 \mathrm{~h}$. A549 cells were treated with Western blot analysis was performed to detect the expression level of the autophagy-associated protein, microtubule associated protein 1 light chain $3 \beta$ (LC3B), and apoptosis-associated proteins such as cleaved caspase- 9 and cleaved caspase-3. CCK8, colony formation, wound healing and Transwell assays were performed to analyze cell proliferation, migration and invasion capacity. Reverse transcription-quantitative PCR (RT-qPCR) was used to analyze the mRNA expression levels of LC3B and beclin-1, and the apoptosis rate was analyzed by flow cytometry. The $\mathrm{IC}_{50}$ of EPI was $0.03 \mu \mathrm{g} / \mathrm{ml}$. The CCK8 results demonstrated that the cell survival rate was lower in CQ + EPI-treated cells when compared with the individual treatment groups. The colony formation results revealed that the number of clones in the EPI + CQ-treated group was reduced compared with EPI or CQ treatment alone. The wound healing assay revealed that migration was reduced in the EPI + CQ-treated group compared with the other treatment groups, and the Transwell results indicated that the number of cells passing through the Matrigel and membrane was lowest in the CQ + EPI treatment group. The mRNA
\end{abstract}

Correspondence to: Professor Yong-Jun Liu, Department of Biochemistry and Molecular Biology, Guangdong Medical University, 1 Xincheng Road, Songshan Lake, Dongguan, Guangdong 523808, P.R. China

E-mail: liuyongjun@gdmu.edu.cn

*Contributed equally

Key words: lung cancer, autophagy, chloroquine, epirubicin, chemotherapy resistance expression levels of LC3B and beclin-1 were increased in the CQ + EPI group by 51.5 and $61.2 \%$, respectively, when compared with the control group. The results indicated that LC3B protein expression was enhanced by EPI in a concentration-dependent manner, and the protein levels of cleaved caspase- 3 and cleaved caspase-9 were higher in the combination group than in the EPI alone group. The flow cytometry results demonstrated that the apoptosis rate was highest in the EPI + CQ group. In conclusion, the autophagy inhibitor CQ increased the sensitivity of A549 cells to EPI, and the underlying mechanism of action may be associated with the activation of apoptosis.

\section{Introduction}

Lung cancer is the most commonly occurring cancer worldwide (1). Lung cancer is subdivided into small cell lung cancer and non-small cell lung cancer (NSCLC) (2). Surgery is regarded as the most effective treatment for early stage lung cancer; however, radiotherapy, chemotherapy and targeted therapy are often the last option for patients with advanced lung cancer, for whom surgery is no longer an option (2). A combination of anthracyclines and platinum drugs are well-established, safe and effective first-line chemotherapy regimens $(3,4)$. Epirubicin (EPI) is the 4 ' epimer of the anthracycline antibiotic doxorubicin, and has been used alone or in combination with other cytotoxic agents for the treatment of a variety of malignancies (5). It has been proposed that EPI functions via several underlying mechanisms: i) Inhibition of DNA replication and transcription; ii) inhibition of topoisomerase II activity; and iii) generation of reactive oxygen species (ROS). Liu et al (6) investigated the mechanism of EPI chemotherapy in the human large cell lung cancer cell line H460. It was revealed that regulation of Glycoprotein 130 (gp130) signaling serves a critical role in epirubicin-based chemotherapy, and the antitumor efficacy of EPI depends on the degradation of gp130. It was also proposed that if gp130 has S-782-A mutation, it will increase the autophagy of lung cancer cells, which may help them survive the crisis. And they found that epirubicin-resistant cells expressed high level 
of gp130 (6). In a phase III clinical trial, Wachters et al (7) hypothesized that EPI or cisplatin combined with gemcitabine may be used as a first-line treatment for advanced non-small cell lung cancer. However, the long-term use of anti-cancer drugs often results in tumor resistance, which greatly limits the effects of EPI in lung cancer treatment (8). Previous studies have reported that tumor resistance may be associated with increased autophagy (9-13), and inhibiting autophagy may enhance the role of chemotherapeutic drugs. Autophagy is a way for cells to survive crisis; they can produce the energy and substance necessary for cells survival by degrading their subcellular organelles, so as to maintain the homeostasis. In the tumor environment, autophagy can help tumor cells resist radiation or chemotherapy $(14,15)$. Chloroquine (CQ) is a commonly used autophagy inhibitor that functions by disrupting the acidic environment of lysosomes and inhibiting the fusion of autophagosomes with lysosomes (16). A study by Chou et al (17) revealed that cotreatment with CQ enhanced the cytotoxicity of C2-ceramide by 2.4- and 3.4-fold respectively compared with single treatment in the two NSCLC cell lines H460 and H1299; moreover, combination treatment significantly reduced the migration and invasion capability of both cell lines. Furthermore, in vivo analysis demonstrated that a combination of $\mathrm{C} 2$-ceramide and CQ resulted in a significant tumor-inhibition efficacy in the zebrafish xenograft model compared with single treatment groups, which suggests that the combination was reliable for lung cancer treatment (17). The present study investigated whether the autophagy inhibitor CQ can improve the sensitivity of the A549 lung cancer cell line to EPI, and attempted to elucidate the mechanisms involved.

\section{Materials and methods}

Cell culture. A549 lung cancer cells were donated by Professor Qian HL, Institute of Oncology, Chinese Academy of Medical Sciences (Beijing, China) were cultured in RPMI-1640 medium (Gibco; Thermo Fisher Scientific, Inc.) containing 10\% fetal bovine serum (Shanghai Shengong Biology Engineering Technology Service, Co., Ltd.), $100 \mathrm{U} / \mathrm{ml}$ penicillin and $100 \mu \mathrm{g} / \mathrm{ml}$ streptomycin. The incubator temperature was $37^{\circ} \mathrm{C}$, the $\mathrm{CO}_{2}$ concentration was $5 \%$ and the medium was changed every other day. Cells in the logarithmic growth phase were used for subsequent experiments.

Measurement of the $I C_{25}, I C_{50}$ and $I C_{75}$ of EPI. A549 cells in the logarithmic growth phase were seeded in 96-well plates $(1,000$ cells/well). After $24 \mathrm{~h}$ in the aforementioned culture conditions, cells were treated with EPI (200 $\mu$; MedChemExpress) at concentrations of 0, 0.01, 0.02, 0.04, 0.08 and $0.16 \mu \mathrm{g} / \mathrm{ml}$. At $72 \mathrm{~h}$ following treatment, $10 \%$ Cell Counting Kit-8 (CCK8) reagent (cat. no. CK04-13; Dojindo Molecular Technologies, Inc.) was added to each well and to a well without cells, which served as a blank control. The cells were incubated at $37^{\circ} \mathrm{C}$ for $1.5 \mathrm{~h}$, and the optical density (OD) at $450 \mathrm{~nm}$ was determined using a UV spectrophotometer. The survival rate of cells was calculated according to the following formula: Survival rate $(\%)=\left(\mathrm{A}_{\text {experimental group }}-\mathrm{A}_{\text {blank group }}\right) /\left(\mathrm{A}_{\text {control }}\right.$ group $\left.-A_{\text {blank group }}\right) \times 100$. Inhibition rate $(\%)=1$-survival rate. There were three replicates in each experiment and three experimental repeats were performed.
Cell proliferation ability. Cells were plated as described previously. After $24 \mathrm{~h}, \mathrm{~A} 549$ cells were treated with $10 \mu \mathrm{M} \mathrm{CQ}$ [TCI (Shanghai) Chemical Development Co., Ltd.], $0.03 \mu \mathrm{g} / \mathrm{ml}$ EPI $\left(\mathrm{IC}_{50}\right)$ or $10 \mu \mathrm{M} \mathrm{CQ}$ and $0.03 \mu \mathrm{g} / \mathrm{ml}$ EPI. Following a $72 \mathrm{~h}$ incubation at $37^{\circ} \mathrm{C}$, the $\mathrm{OD}$ values of each group were measured using CCK8 according to the previously described protocol. There were three replicates for each experiment and three experimental repeats were performed. The survival rate and inhibition rate were calculated as described previously.

Colony formation assay. A549 cells in the logarithmic growth phase were seeded into 6-well plates at a density of 400 cells/well, and incubated in the aforementioned culture conditions. After $12 \mathrm{~h}, 500 \mu \mathrm{l}$ complete RPMI-1640 media, and $10 \mu \mathrm{M} \mathrm{CQ}, 0.01 \mu \mathrm{g} / \mathrm{ml}$ EPI or $10 \mu \mathrm{M} \mathrm{CQ}+0.01 \mu \mathrm{g} / \mathrm{ml}$ EPI were added to cells and incubated at $37^{\circ} \mathrm{C}$. After $72 \mathrm{~h}$, each drug treatment was replaced with complete RPMI-1640 medium and culture was continued. The experiment was terminated when macroscopic colonies appeared. Colonies were fixed in methanol for $20 \mathrm{~min}$ at $25^{\circ} \mathrm{C}$ and stained with $0.1 \%$ crystal violet for $30 \mathrm{~min}$ at $25^{\circ} \mathrm{C}$ and the number of clones was counted. There were three replicates in each experiment and three experimental repeats were performed.

Invasion assay. Matrigel (BD Biosciences), diluted 1:6 (75 $\mu 1 /$ well), was plated on the upper chambers of Transwell inserts. A549 cells in the logarithmic growth phase $\left(1.5 \times 10^{4}\right.$ cells/well $)$ were added into the upper chambers with serum-free medium (cells were serum starved prior to seeding). Additionally, $600 \mu 1$ RPMI-1640 supplemented with $20 \%$ FBS was added to the lower chambers. After 6 h, A549 cells were treated with CQ $(10 \mu \mathrm{M})$, EPI (IC50) or both (drugs were diluted in serum-free RPMI-1640 media). After $72 \mathrm{~h}$, the chambers were removed, and the invading cells were fixed in methanol for $20 \mathrm{~min}$ at $25^{\circ} \mathrm{C}$ and stained with $0.1 \%$ crystal violet for $30 \mathrm{~min}$ at $25^{\circ} \mathrm{C}$. A cotton swab was used to remove cells in the upper chamber and number of cells passing through the Matrigel and the membrane were counted using a light microscope (Nikon Corp.; magnification, x100). There were three replicates in each experiment and three experimental repeats were performed.

Wound-healing assay. A549 cells in the logarithmic growth phase were seeded at a density of $1 \times 10^{5}$ cells per well into a 12-well plate and incubated for $24 \mathrm{~h}$ at $37^{\circ} \mathrm{C}$ and $5 \% \mathrm{CO}_{2}$. After $24 \mathrm{~h}$, a vertical scratch-wound was drawn in the center of each well using a sterile tip, and PBS was used to wash off debris. RPMI-1640 supplemented with $2 \%$ FBS, and $10 \mu \mathrm{M}$ CQ, $0.03 \mu \mathrm{g} / \mathrm{ml}$ EPI or $10 \mu \mathrm{M} \mathrm{CQ}+0.03 \mu \mathrm{g} / \mathrm{ml}$ EPI was added to each well (CQ and EPI were diluted in RPMI-1640 containing $2 \%$ FBS). After $72 \mathrm{~h}$, the drugs were replaced with RPMI-1640 supplemented with 2\% FBS alone. Cell scratches were observed under a light microscope (Nikon; magnification, $\mathrm{x} 100)$ at 0,24 and $48 \mathrm{~h}$. There were three replicates in each experiment and three experimental repeats were performed.

Microtubule associated protein 1 light chain $3 \alpha$ (LC3A) and $3 \beta(L C 3 B)$ protein expression. A549 cells in the logarithmic growth phase were seeded at a density of $1.8 \times 10^{5}$ cells per well in 6-well plates and incubated overnight at $37^{\circ} \mathrm{C}$ and 
$5 \% \mathrm{CO}_{2}$. The cells were treated with different concentrations of EPI $(0,0.01,0.03$ and $0.08 \mu \mathrm{g} / \mathrm{ml})$, CQ $(10 \mu \mathrm{M})$, EPI $(0.03 \mu \mathrm{g} / \mathrm{ml})$ or CQ $(10 \mu \mathrm{M})+$ EPI $(0.03 \mu \mathrm{g} / \mathrm{ml})$. After $72 \mathrm{~h}$, total proteins were extracted and the protein concentration was determined using the BCA method (Thermo Fisher Scientific, Inc.). Proteins were separated by SDS-PAGE (the separation gel and the concentrated gel were 15 and 5\%, respectively). The wet transfer method was performed at $200 \mathrm{~mA}$ for $120 \mathrm{~min}$ to transfer proteins to a polyvinylidene difluoride (PVDF) membrane. Membranes were blocked at $25^{\circ} \mathrm{C}$ in $5 \%$ skimmed milk powder for $1.5 \mathrm{~h}$, and then incubated with the primary antibody Rabbit Anti-MAP1LC3A antibody (cat. no. ab52628; Abcam) or rabbit anti-human LC3B monoclonal antibody (cat. no. 3868; Cell Signaling Technology, Inc.) overnight at $4^{\circ} \mathrm{C}$ on a shaker. Secondary antibody (horseradish peroxidase-labeled goat anti-rabbit antibody; cat. no. 061617170620; Shanghai Biyuntian Corporation) was added to the membrane and incubated at room temperature for $1 \mathrm{~h}$ on a shaker. Hypersensitive luminescence solution (Applygen Technologies, Inc.) was used to detect proteins and PVDF membranes were exposed in a darkroom. The software Quantity One 4.6.2 (Bio-Rad Laboratories, Inc.) was used for density analysis. The experiment was repeated three times.

Fluorescein isothiocyanate-Annexin V/propidium iodide apoptosis analysis. A549 cells in the logarithmic growth cells were seeded in 6 -well plates $\left(1 \times 10^{5}\right.$ cells/well) and incubated overnight. Cells were incubated with RPMI-1640 medium, and CQ $(10 \mu \mathrm{M}), \mathrm{EPI}(0.03 \mu \mathrm{g} / \mathrm{ml})$ or CQ $(10 \mu \mathrm{M})$ + EPI $(0.03 \mu \mathrm{g} / \mathrm{ml})$ for $72 \mathrm{~h}$. The apoptosis rate of each group was determined according to the manufacturer's protocol (Annexin V-FITC Apoptosis Detection Kit; cat. no. CA1020, Beijing Solarbio Bio-Technology Co., Ltd.). The kit contains Annexin V-FITC, Propidium Iodide and binding buffer. Annexin V-FITC is stored frozen at $-20^{\circ} \mathrm{C}$, Propidium Iodide and Binding buffer are stored at $4^{\circ} \mathrm{C}$ and protected from light.). Digestion of cells was performed using trypsin without EDTA and the cells were then centrifuged at $260 \mathrm{x}$ g for $5 \mathrm{~min}$ at $4^{\circ} \mathrm{C}$ and washed twice with PBS. A total of $5 \times 10^{5}$ cells were then added to $500 \mu \mathrm{l}$ of buffer to resuspend them. Subsequently, $5 \mu \mathrm{l}$ of Annexin V-FITC and $5 \mu \mathrm{l}$ Propidium Iodide was added to the cells and mixed well. The cells were let in the dark for $5 \mathrm{~min}$ at room temperature. Flow cytometry (BD FACSCanto $^{\mathrm{TM}}$ II; Becton, Dickinson and Company) using FACSDiva version 6.1.2 software (Becton, Dickinson and Company) was then performed within $1 \mathrm{~h}$. The experiment was repeated three times. The Q2 (AnnexinV-FITC ${ }^{+} / \mathrm{PI}^{+}$) and Q4 (AnnexinV-FITC ${ }^{+} / \mathrm{PI}^{-}$) quadrants represent late apoptotic cells and early apoptotic cells, respectively. The apoptotic rate was calculated using the dot plots of cells in the Q2 and Q4 quadrants.

Reverse transcription-quantitative PCR A549 cells in the logarithmic growth phase were seeded $1 \times 10^{5}$ cells/well in a 6-well plate and incubated overnight. Cells were incubated with RPMI-1640 medium supplemented with $10 \mu \mathrm{M}$ CQ alone, $0.03 \mu \mathrm{g} / \mathrm{ml}$ EPI alone or $10 \mu \mathrm{M} \mathrm{CQ}+0.03 \mu \mathrm{g} / \mathrm{ml} \mathrm{EPI}$ for $72 \mathrm{~h}$. Total RNA was extracted using TRIzol ${ }^{\mathrm{TM}}$ Reagent (Invitrogen; Thermo Fisher Scientific, Inc.; cat. no. 15596026) and the concentration was determined. The reverse transcription reaction system of $1 \mathrm{c} 3 \mathrm{~b}$ and beclicn-1 consisted of: 5X PrimeScript RT Master Mix (cat. no. DRR037A; Takara Bio, Inc.) $2 \mu \mathrm{l}$, total RNA $1 \mu \mathrm{g}$, RNasefree Super Pure $\mathrm{H}_{2} \mathrm{O}$ up to $10 \mu \mathrm{l}$. The reaction conditions were as follows: $65^{\circ} \mathrm{C}$ for $10 \mathrm{~min} ; 25^{\circ} \mathrm{C}$ for $10 \mathrm{~min}$ followed by $50^{\circ} \mathrm{C}$ for $1 \mathrm{~h}$. The quantitative PCR reaction system of $1 \mathrm{c} 3 \mathrm{~b}$ and beclicn-1 consisted of: 2X FastStart Universal SYBR 25.0 $\mu$ l (FastStart Universal SYBR Green Master (ROX), cat. no. 04913914001, Roche Diagnostics), forward primer $(12.5 \mu \mathrm{M}) 0.5 \mu \mathrm{l}$, reverse primer $(12.5 \mu \mathrm{M}) 0.5 \mu \mathrm{l}$, cDNA template $1.0 \mu \mathrm{l}$, RNasefree Super Pure $\mathrm{H}_{2} \mathrm{O}$ up to $45 \mu \mathrm{l}$. The reaction conditions were as follows: $95^{\circ} \mathrm{C}$ for $30 \mathrm{sec} ; 95^{\circ} \mathrm{C}$ for $15 \mathrm{sec} ; 60^{\circ} \mathrm{C}$ for $30 \mathrm{sec}$ for 40 cycles; and $4^{\circ} \mathrm{C}$ for $1 \mathrm{~h}$. Each well in these experiments had three repeated wells and every experiment was repeated three times. The $2^{-\Delta \Delta \mathrm{Cq}}$ analysis method was used to analyze the experimental results (18). The primers sequences are listed in Table I. GAPDH was selected as the reference gene.

Statistical analysis. All experimental data were analyzed using SPSS 17.0 statistical software (SPSS, Inc.) and presented as the mean \pm standard deviation. The $\mathrm{IC}_{50}$ was calculated using Probit regression. Multiple comparisons were performed with one-way analysis of variance followed by Tukey's post hoc test. Prior to data analysis, the homogeneity of variance and normality tests was performed using Bartlett's test. $\mathrm{P}<0.05$ was considered to indicate a statistically significant difference.

\section{Results}

EPI IC ${ }_{25}, I C_{50}$ and $I C_{75}$. The viability of A549 cells was analyzed at $72 \mathrm{~h}$ following treatment with EPI at different concentrations (Table II; Fig. 1A). The $\mathrm{IC}_{25}, \mathrm{IC}_{50}$ and $\mathrm{IC}_{75}$ concentrations of A549 cells treated with EPI for $72 \mathrm{~h}$ were $0.01,0.03$ and $0.08 \mu \mathrm{g} / \mathrm{ml}$, respectively.

EPI and CQ combination therapy enhances the anti-proliferative effect of EPI in A549 cells. The CCK8 assay demonstrated there was no significant difference in the survival rate of cells treated with CQ alone compared with the control group. The survival rate of EPI-treated cells was decreased to $52.5 \%$ compared with the control group $(\mathrm{P}<0.001)$. The survival rate of the EPI + CQ group was decreased to $33.3 \%$ compared with the control group $(\mathrm{P}<0.001)$. The results demonstrated that the combination treatment had a greater effect on cell proliferation compared with EPI or CQ alone (Fig. 1B).

EPI and CQ combination therapy reduces the colony formation ability of A549 lung cancer cells. Colony formation experiments revealed that there were no statistically significant differences between the CQ alone and control groups. The number of colonies in the EPI alone group was decreased to $65.64 \%$ compared with the control group $(\mathrm{P}<0.01$; Fig. 2A and B). The number of colonies in the CQ + EPI group was $\sim 71.09 \%$ of the number in the EPI alone group $(\mathrm{P}<0.05$; Fig. 2A and B). This indicated that CQ combined with EPI reduced the colony formation ability of A549 cells when compared with EPI treatment alone.

EPI and $C Q$ combination therapy reduces the invasion ability of A549 lung cancer cells. The Transwell assay 
Table I. LC3B and GAPDH primer sequences.

Primer sequence (5'-3')

\begin{tabular}{|c|c|c|c|}
\hline Gene & Forward & Reverse & Amplification product length, bp \\
\hline LC3B & ATTTCATCCCGAACGTCTCCT & GCGCTTACAGCTCAATGCTAA & 161 \\
\hline Beclin-1 & GAGATACCGACTTGTTCCTTACG & CTCGCCTTTCTCAACCTCTTCTT & 184 \\
\hline GAPDH & GGACCTGACCTGCCGTCTAG & GTAGCCCAGGATGCCCTTGA & 100 \\
\hline
\end{tabular}

LC3B, microtubule associated protein 1 light chain $3 \beta$.

Table II. The survival rate of A549 cells with different concentrations EPI treated for $72 \mathrm{~h}$.

\begin{tabular}{lcc}
\hline EPI concentration, $\mu \mathrm{g} / \mathrm{ml}$ & OD value & Survival rate \\
\hline 0.00 & $0.868 \pm 0.009$ & $1.000 \pm 0.000$ \\
0.01 & $0.724 \pm 0.093$ & $0.760 \pm 0.068$ \\
0.02 & $0.622 \pm 0.061$ & $0.602 \pm 0.029$ \\
0.04 & $0.451 \pm 0.097$ & $0.407 \pm 0.062$ \\
0.08 & $0.296 \pm 0.025$ & $0.234 \pm 0.040$ \\
0.16 & $0.272 \pm 0.040$ & $0.175 \pm 0.065$
\end{tabular}

Data are presented as the mean \pm standard deviation. EPI, epirubicin; OD, optical density.

results revealed that the number of cells that passed through the Matrigel and membrane was lower in the EPI alone group than in the control group ( $324 \pm 7.937$ vs. $574 \pm 23.896$; $\mathrm{P}<0.01)$. The number of cells in the combination group was lower compared with that in the EPI alone group $(173 \pm 11.240$ vs. $324 \pm 7.937 ; \mathrm{P}<0.05$ ). There was no significant difference between the CQ alone group and the control group (Fig. 2C and D).

EPI and CQ combination therapy reduces the migration ability of A549 lung cancer cells. The results of the wound-healing assay demonstrated that the scratch widths $(\mu \mathrm{m})$ of the control, CQ alone, EPI alone and the combination groups were $719.7 \pm 7.57,730.7 \pm 5.69,724.0 \pm 6.25$ and $723.6 \pm 6.66$, respectively. After $72 \mathrm{~h}$, the results of the wound-healing assay demonstrated that the percentage wound closure of the control, CQ alone, EPI alone and the combination groups were $40.65 \pm 0.563,47.72 \pm 2.756,46.03 \pm 1.380$ and $24.75 \pm 0.661$, respectively. And after $96 \mathrm{~h}$, the percentage of wound closure (\%) were $85.65 \pm 0.892,83.65 \pm 0.595,73.04 \pm 0.375$ and $44.53 \pm 2.222$, respectively, and at $108 \mathrm{~h}$ the $\%$ values were $100.0 \pm 0.000,100.0 \pm 0.000,80.32 \pm 1.558$ and $53.76 \pm 2.140$, respectively. One-way analysis of variance revealed that there was no significant difference between the control group and the CQ alone group $(\mathrm{P}>0.05)$; however, there was a significant difference between the EPI alone group and the control group $(\mathrm{P}<0.01$ at $72 \mathrm{~h} ; \mathrm{P}<0.05$ at 96 and $108 \mathrm{~h})$, and between the EPI alone group and the combination group $(\mathrm{P}<0.001$; Fig. 2E and F).
EPI enhances autophagy in A549 lung cancer cells. A549 cells were treated with different concentrations $(0.01,0.03$ and $0.08 \mu \mathrm{g} / \mathrm{ml}$ ) of EPI for $72 \mathrm{~h}$ and the expression levels of LC3A and LC3B protein were analyzed. The results demonstrated that the expression ratio of LC3B to LC3A in EPI-treated A549 cells increased in a concentration-dependent manner (Fig. 3). The expression ratio of LC3B to LC3A have previously been used to evaluate the extent of autophagy (19); therefore, these results suggest that EPI enhanced autophagy in A549 cells.

EPI can induce the mRNA expression of the autophagy-associated genes LC3B and beclin-1. RT-qPCR revealed the expression of the autophagy-associated gene LC3B was significantly increased in the EPI and combination groups when compared with the control group $(\mathrm{P}<0.05$; Fig. 4A). The expression of beclin-1 was also significantly increased in the EPI and combination groups when compared with the control group $(\mathrm{P}<0.01$; Fig. 4B). Taken together, these results suggest that EPI treatment induced autophagy in A549 cells.

CQ inhibits autophagy in A549 lung cancer cells. Western blot analysis demonstrated that there was a significant difference in the expression of LC3B between the control and the CQ alone groups $(\mathrm{P}<0.001)$. A significantly difference was also observed between the EPI alone and combination groups $(\mathrm{P}<0.001$; Fig. 4C). This effect was increased following CQ treatment, indicating that $\mathrm{CQ}$ inhibited the downstream degradation of autophagy.

Combination therapy increases apoptosis of A549 lung cancer cells. Flow cytometry analysis revealed that there was no significant difference in the apoptosis rate between the control group and the CQ alone group; however, the apoptosis rate was significantly increased in the EPI alone group compared with the control group $(\mathrm{P}<0.01)$. In addition, the apoptosis rate of the combination group was significantly higher than that of the EPI alone group $(\mathrm{P}<0.05$; Fig. $4 \mathrm{D})$.

\section{Discussion}

High morbidity and mortality rates make lung cancer a severe threat to human health (1). Chemotherapy serves an important role in the treatment of lung cancer; however, even the most effective chemotherapy has only a $30-50 \%$ response rate (20). Drug resistance of tumor cells has become an increasingly prominent setback during chemotherapy, as it severely limits 

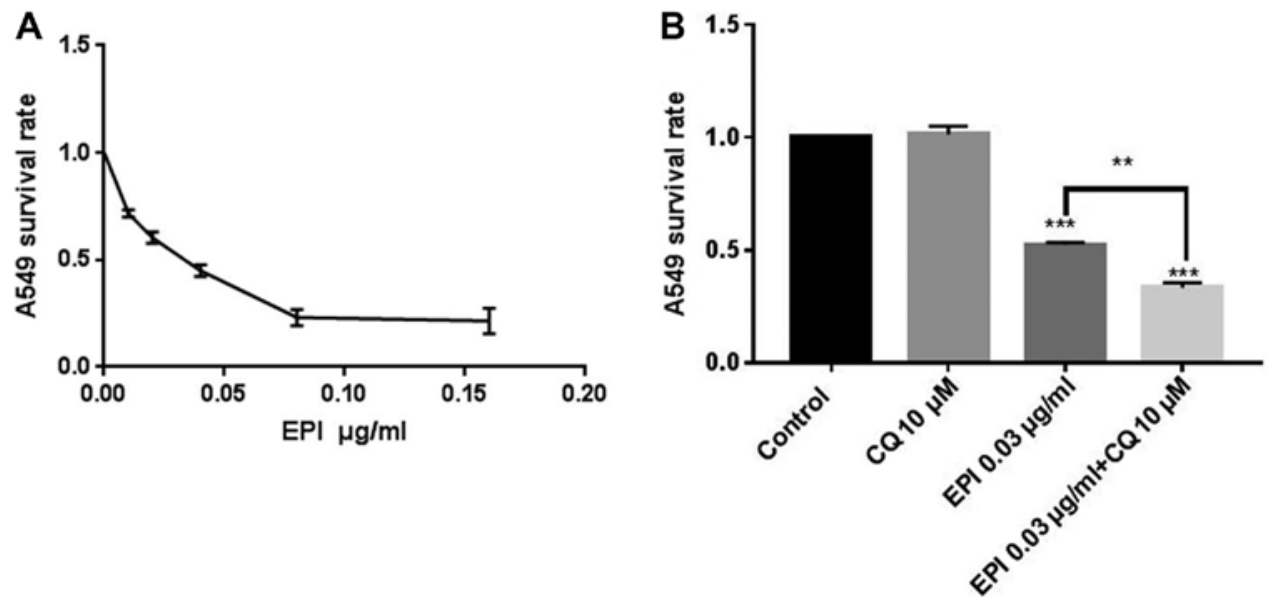

Figure 1. A549 cell survival rate. (A) Fold change in the survival rate of A549 cells treated with different concentrations of EPI for 72 h. (B) Histogram depicting the survival rate of A549 lung cancer cells. ${ }^{* * *} \mathrm{P}<0.01,{ }^{* * *} \mathrm{P}<0.001$ vs. control or as indicated. EPI, epirubicin.

A

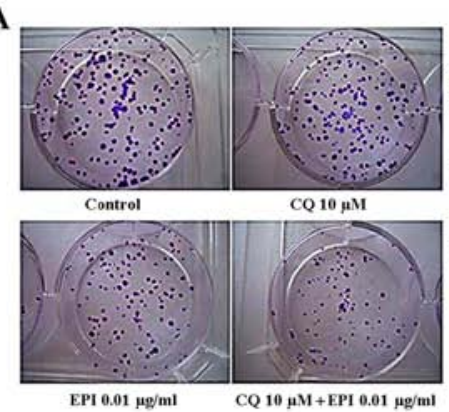

E

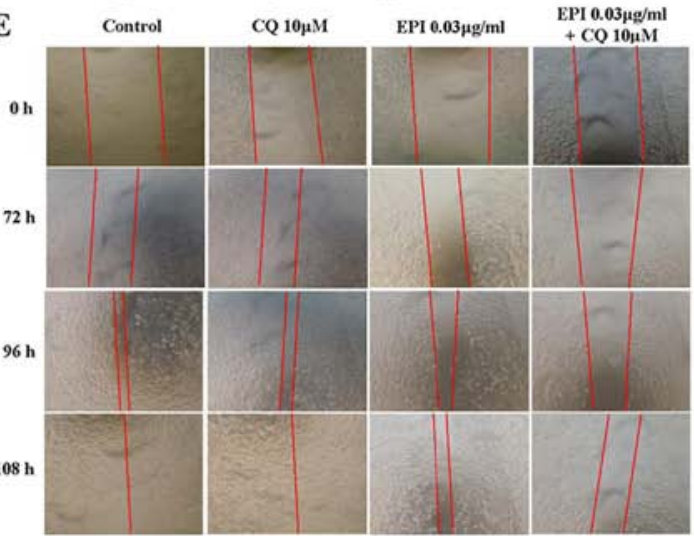

C
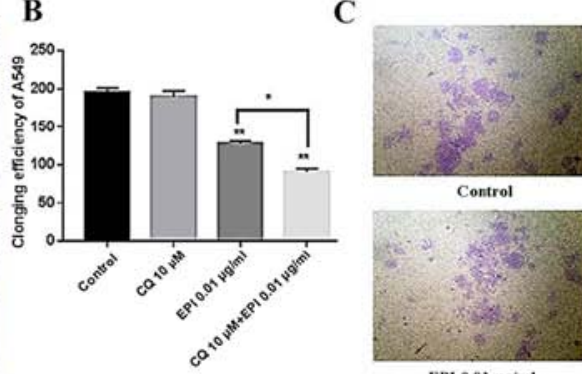

EP1 $0.03 \mu \mathrm{m} / \mathrm{ml}$

F

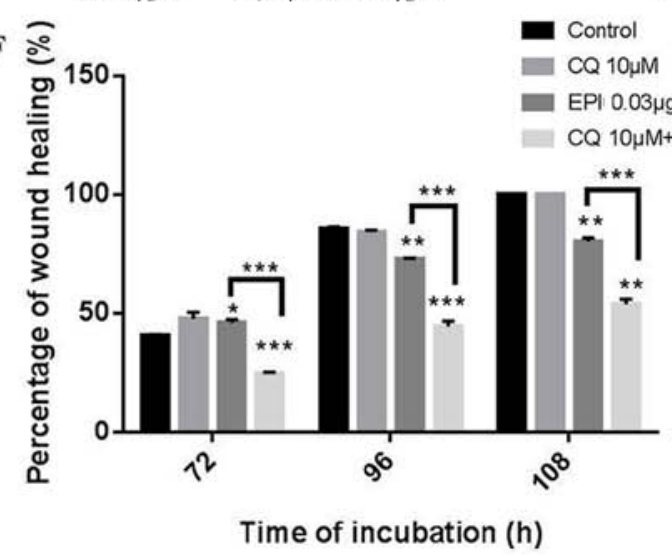

Figure 2. Colony formation, Transwell and wound healing assays. (A) Colony formation in each group. (B) Quantification of colony formation in each group. ${ }^{*} \mathrm{P}<0.05,{ }^{* *} \mathrm{P}<0.01$ vs. control or as indicated. (C) Images of cells passed through the Matrigel and membrane (x400 magnification). (D) Quantification of the number of cells passed through the Matrigel and membrane. ${ }^{*} \mathrm{P}<0.05,{ }^{* *} \mathrm{P}<0.01$ vs. control group or as indicated. (E) Images from the wound healing assay for each group after $108 \mathrm{~h}$ (x100 magnification). (F) Scratch width quantification after 72, 96 and $108 \mathrm{~h} .{ }^{*} \mathrm{P}<0.05,{ }^{* * *} \mathrm{P}<0.01,{ }^{* * *} \mathrm{P}<0.001 \mathrm{vs}$. control or as indicated. EPI, epirubicin; CQ, chloroquine.

the efficacy of chemotherapeutic drugs, which in turn has meant that drug resistance has been the focus of an increasing amount of studies (21). Multiple studies have reported that autophagy may be involved in chemotherapeutic resistance developed in lung cancer (20,22-25), and that inhibiting autophagy may reduce resistance and enhance the efficacy of chemotherapeutics.

Autophagy protects cells from DNA damage during chemotherapy or targeted therapy, and maintains intracellular environmental stability, which may be one of the mechanisms that contribute to chemotherapy resistance $(26,27)$. Autophagy can promote cell survival under conditions of metabolic stress, exhibiting an oncogenic function (28). During autophagy, the C-terminus of LC3 precursor protein is hydrolyzed by autophagy related (Atg) 4 to remove a polypeptide and expose a glycine residue (29). The LC3A protein is then distributed in the cytosol, and Atg7 transports LC3A to Atg3, which covalently binds LC3A and phosphatidylethanolamine to form lipophilic LC3B, which mediates autophagosome membrane elongation. Then autophagosome is formed by closure, and then fused with endosomes or lysosomes to form autolysosomes. Finally, the whole autophagy process is completed by degradation (29). 
$\mathbf{A}$

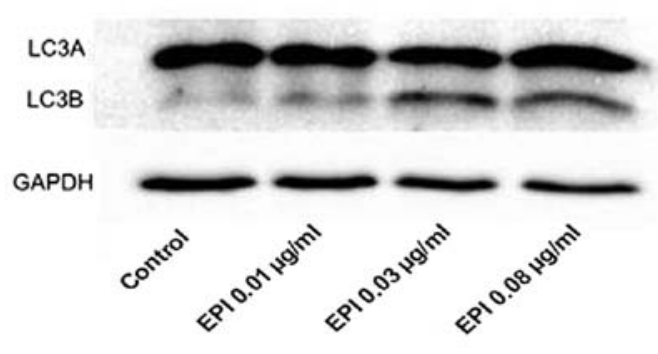

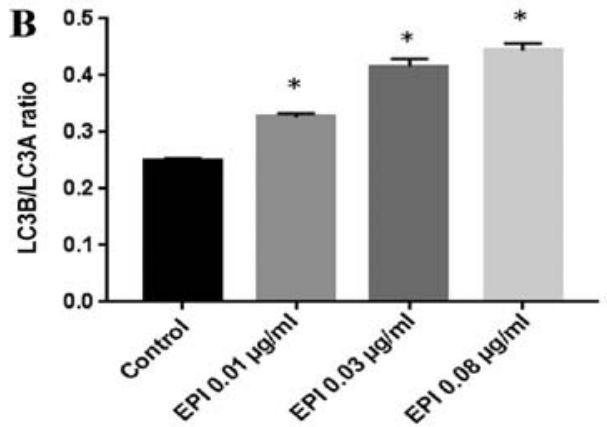

Figure 3. Effect for EPI on LC3B protein expression. Cells were treated with different concentrations $(0.01,0.03$ and $0.08 \mu \mathrm{g} / \mathrm{ml})$ of EPI for $72 \mathrm{~h}$. (A) Western blot analysis of LC3A and LC3B in each group. (B) Densitometry analysis of the protein expression ratio of LC3B to LC3A in each group. " $\mathrm{P}<0.05$ vs. control group. EPI, epirubicin; LC3A, microtubule associated protein 1 light chain $3 \alpha$; LC3B, microtubule associated protein 1 light chain $3 \beta$.
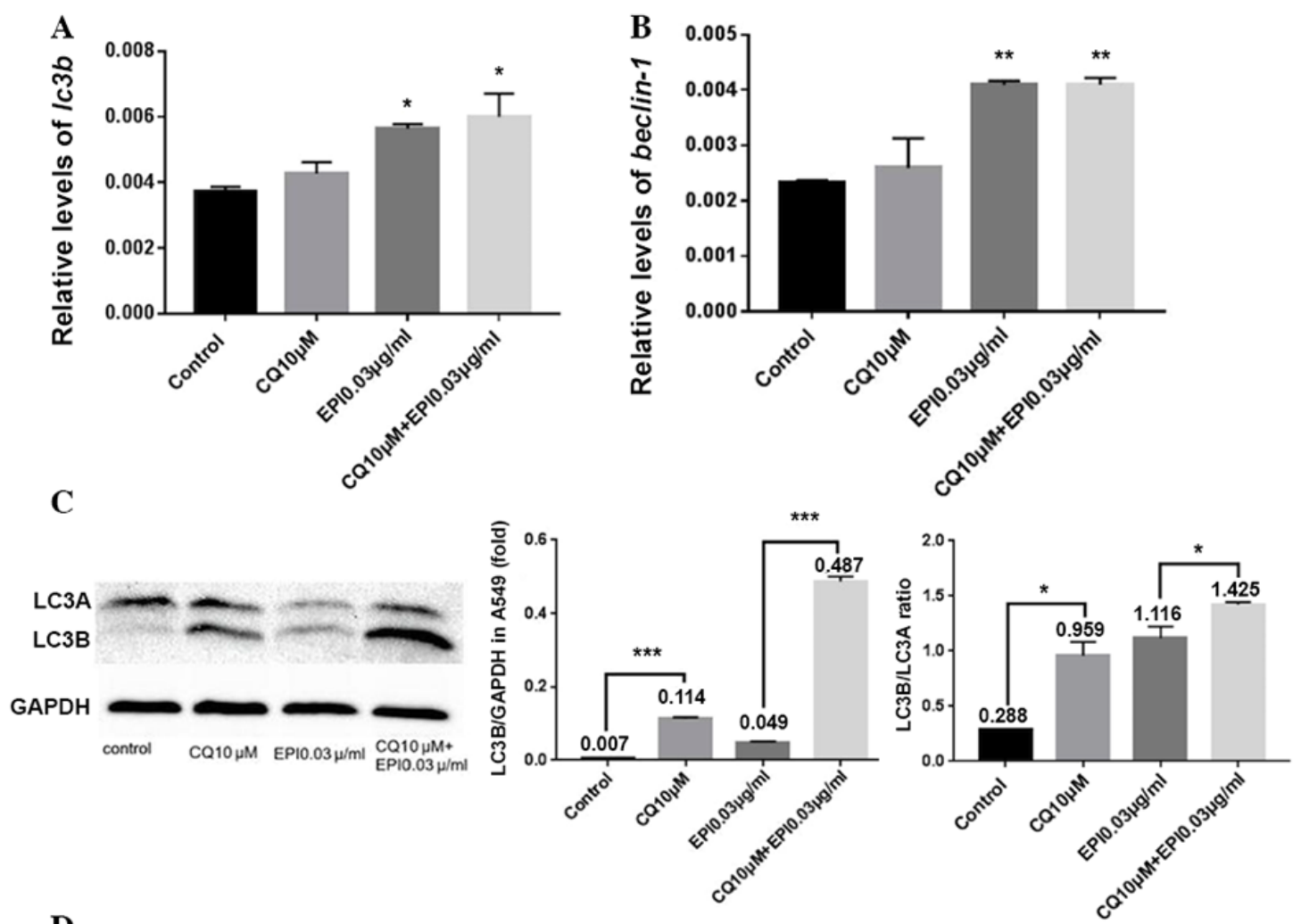

D
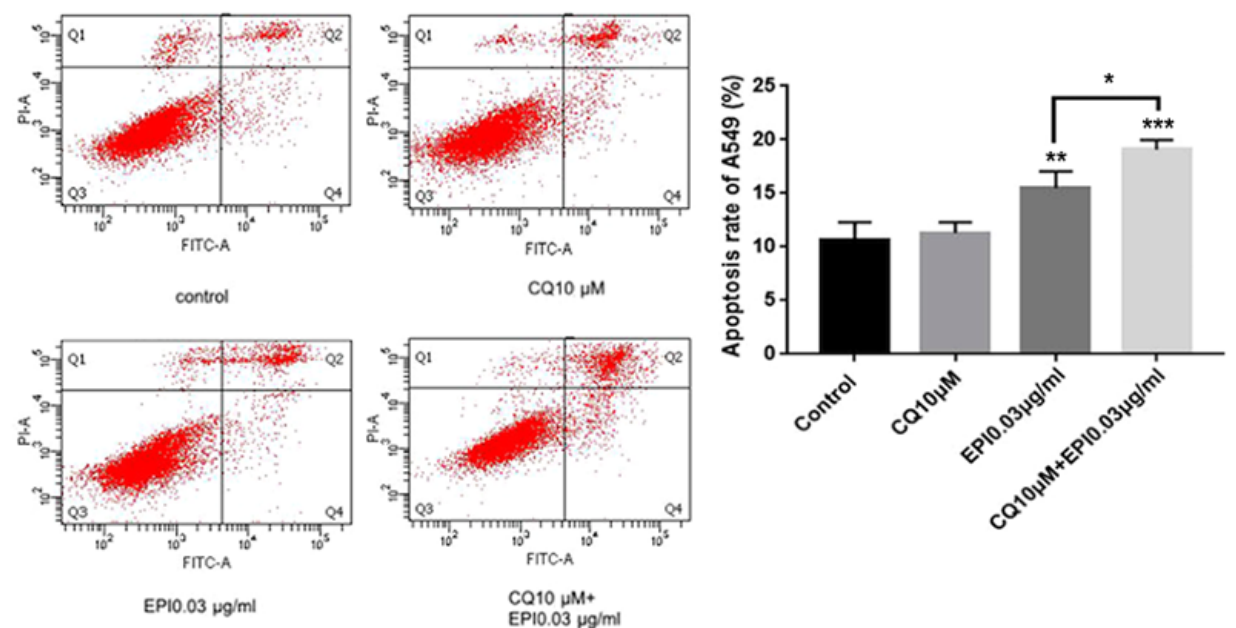

Figure 4. Reverse transcription-quantitative PCR, western blot analysis and cell apoptosis assay. (A) RNA expression levels of LC3B. (B) RNA expression levels of beclin-1. (C) Western blot analysis of LC3A and LC3B in each group, and densitometric analysis of the protein bands (D) Flow cytometry analysis of apoptosis and quantification of the apoptosis rate. ${ }^{*} \mathrm{P}<0.05,{ }^{* * *} \mathrm{P}<0.01,{ }^{* * *} \mathrm{P}<0.001 \mathrm{vs}$. control group or as indicated. EPI, epirubicin; CQ, chloroquine; LC3A, microtubule associated protein 1 light chain $3 \alpha$; LC3B, microtubule associated protein 1 light chain $3 \beta$. 
The Atg12-Atg5-Atg16 complex is required for this process; therefore, the level of cellular autophagy formation can be assessed using the ratio of $\mathrm{LC} 3 \mathrm{~B}$ to $\mathrm{LC} 3 \mathrm{~A}$ proteins, and an increased ratio is indicative of enhanced autophagy formation (19). Increased LC3B protein may indicate an increase in autophagy formation, or it may indicate that the downstream degradation of autophagy is inhibited, and the hydrolysis of LC3B is reduced, therefore resulting in an increase in LC3B protein content (29).

The findings of the present study demonstrated that treatment of A549 lung cancer cells with CQ in conjunction with EPI reduced the proliferation, migration and invasion of A549 cells, suggesting that the combination of an autophagy inhibitor with EPI may enhance the anti-tumor activity. Additionally, this combination of drugs can increase the apoptosis of A549 cells. The results also suggest that the expression of the LC3B protein was higher in the CQ group than in the control group, and LC3B protein expression in the combination group was higher than that in control and EPI groups. This indicates that CQ inhibited cell autophagy. CQ inhibits the fusion of autophagosome and lysosomes, which reduces the degradation of LC3B protein resulting in increased LC3B protein levels (16). This may be the mechanism by which the combination regimen is more effective against A549 cells than their use alone. These results suggest that EPI can induce autophagy of A549 lung cancer cells. When combined with EPI, CQ can reduce EPI-induced autophagy and, thus, enhance the anti-tumor effect of EPI.

A previous study reported that treatment of NSCLC cells with an autophagy inhibitor combined with gefitinib significantly increased the expression of caspase-3 (15). In the present study, flow cytometry was used to detect apoptosis. The results demonstrated the apoptosis rate was higher following the combination treatment than in cells treated with EPI alone. Chemotherapeutics cause the release of cytochrome c into the cytoplasm by damaging the mitochondria and altering mitochondrial membrane potential (30). Cytochrome c release activates the caspase cascade, which induces apoptosis (31). Autophagy can eliminate damaged mitochondria in cells to maintain intracellular homeostasis (32-34). In addition, previous studies have demonstrated that inhibition of autophagy can increase mitochondrial aggregation and intracellular damage $(35,36)$, which may be the mechanism by which CQ promotes autophagy-induced apoptosis.

In summary, EPI treatment of the A549 lung cancer cell line promoted autophagy, and the induction of autophagy was concentration-dependent. The autophagy inhibitor, CQ, combined with EPI increased the ability of EPI to inhibit the proliferation, invasion and migration of A549 cells, exhibiting a synergistic effect. Consequently, it was hypothesized that the mechanism of this synergistic effect may be associated with increased apoptosis. The potential mechanism by which inhibiting autophagy increases apoptosis may be mediated by intracellular aggregation of damaged mitochondria; however, the detailed processes involved require further investigation. With continuous research into this synergistic effect, the use of autophagy inhibitors in combination with traditional chemotherapeutic drugs has the potential to become a novel treatment plan. These findings provide novel ideas for a clinical solution to cancer chemotherapy resistance.

\section{Acknowledgements}

The authors would like to thank Professor Qian HL of Cancer Research Institute of Chinese Academy of Medical Sciences (Beijing, Chian) for providing the A549 lung cell line.

\section{Funding}

The present study work was supported by the National Natural Science Foundation of China (grant no. 81071853).

\section{Availability of data and materials}

The datasets used and/or analyzed during the present study are available from the corresponding author on reasonable request.

\section{Authors' contributions}

ALL and JZ were responsible for designing and carrying out the project, and writing and revising the manuscript. SLD, BZ, $\mathrm{XM}$ and CYW performed the cell culture, CCK-8 and flow cytometry experiments. YJL was responsible for the overall design of the experimental scheme, technical guidance, data review and paper revision. All authors read and approved the final manuscript.

\section{Ethics approval and consent to participate}

Not applicable.

\section{Patient consent for publication}

Not applicable.

\section{Competing interests}

The authors declare that they have no competing interests.

\section{References}

1. Bray F, Ferlay J, Soerjomataram I, Siegel RL, Torre LA and Jemal A: Global cancer statistics 2018: GLOBOCAN estimates of incidence and mortality worldwide for 36 cancers in 185 countries. CA Cancer J Clin 68: 394-424, 2018.

2. Sa H, Song P, Ma K, Gao Y, Zhang L and Wang D: Perioperative targeted therapy or immunotherapy in non-small-cell lung cancer. OncoTargets Ther 12: 8151-8159, 2019.

3. Jacot W, Pujol JL, Chakra M, Molinier O, Bozonnat MC, Gervais R and Quantin X: Epirubicin and ifosfamide in relapsed or refractory small cell lung cancer patients. Lung Cancer 75: 213-216, 2012.

4. Chen W, Yang Z, Deng G and Ye H: High-dose epirubicin combination therapy in the treatment of 48 cases with advanced chest malignant tumors. China Oncol 11: 355-356, 2001 (In Chinese).

5. Plosker GL and Faulds D: Epirubicin. A review of its pharmacodynamic and pharmacokinetic properties, and therapeutic use in cancer chemotherapy. Drugs 45: 788-856, 1993.

6. Liu F, Jin H, Shen J, Wu D, Tian Y and Huang C: Gp130 degradation induced by epirubicin contributes to chemotherapy efficacy. Biochem Biophys Res Commun 519: 572-578, 2019.

7. Wachters FM, Van Putten JW, Kramer H, Erjavec Z, Eppinga P, Strijbos JH, de Leede GP, Boezen HM, de Vries EG and Groen HJ: First-line gemcitabine with cisplatin or epirubicin in advanced non-small-cell lung cancer: A phase III trial. Br J Cancer 89: 1192-1199, 2003. 
8. Owonikoko TK, Ramalingam SS and Belani CP: Maintenance therapy for advanced non-small cell lung cancer: Current status, controversies, and emerging consensus. Clin Cancer Res 16 2496-2504, 2010.

9. Cianfanelli V, Fuoco C, Lorente M, Salazar M, Quondamatteo F, Gherardini PF, De Zio D, Nazio F, Antonioli M, D'Orazio M, et al: AMBRA1 links autophagy to cell proliferation and tumorigenesis by promoting c-Myc dephosphorylation and degradation. Nat Cell Biol 17: 20-30, 2015.

10. Komatsu M, Waguri S, Koike M, Sou YS, Ueno T, Hara T, Mizushima N, Iwata J, Ezaki J, Murata S, et al: Homeostatic levels of p62 control cytoplasmic inclusion body formation in autophagy-deficient mice. Cell 131: 1149-1163, 2007.

11. Liu JT, Li WC, Gao S, Wang F, Li XQ, Yu HQ, Fan LL, Wei W, Wang $\mathrm{H}$ and Sun GP: Autophagy inhibition overcomes the antagonistic effect between gefitinib and cisplatin in epidermal growth factor receptor mutant non-small-cell lung cancer cells. Clin Lung Cancer 16: e55-e66, 2015.

12. Galluzzi L, Kepp O, Vander Heiden MG and Kroemer G: Metabolic targets for cancer therapy. Nat Rev Drug Discov 12: 829-846, 2013.

13. Hale AN, Ledbetter DJ, Gawriluk TR and Rucker EB III: Autophagy: Regulation and role in development. Autophagy 9: 951-972, 2013.

14. Liu R, Chen Z, Yi X, Huang F, Hu G, Liu D, Li X, Zhou H and Liu Z: 9za plays cytotoxic and proapoptotic roles and induces cytoprotective autophagy through the PDK1/Akt/mTOR axis in non-small-cell lung cancer. J Cell Physiol 234: 20728-20741, 2019.

15. Mizushima N: Autophagy: Process and function. Genes Dev 21: 2861-2873, 2007.

16. Amaravadi RK, Yu D, Lum JJ, Bui T, Christophorou MA, Evan GI, Thomas-Tikhonenko A and Thompson CB: Autophagy inhibition enhances therapy-induced apoptosis in a Myc-induced model of lymphoma. J Clin Invest 117: 326-336, 2007.

17. Chou HL, Lin YH, Liu W, Wu CY, Li RN, Huang HW, Chou CH, Chiou SJ and Chiu CC: Combination therapy of chloroquine and $\mathrm{C}(2)$-ceramide enhances cytotoxicity in lung cancer H460 and H1299 cells. Cancers (Basel) 11: E370, 2019.

18. Livak KJ and Schmittgen TD: Analysis of relative gene expression data using real-time quantitative PCR and the 2(-Delta Delta C(T)) method. Methods 25: 402-408, 2001.

19. Pan Y, Qian JX, Lu SQ, Chen JW, Zhao XD, Jiang Y, Wang LH and Zhang GX: Protective effects of tanshinone IIA sodium sulfonate on ischemia-reperfusion-induced myocardial injury in rats. Iran J Basic Med Sci 20: 308-315, 2017.

20. Lee JG, Shin JH, Shim HS, Lee CY, Kim DJ, Kim YS and Chung KY: Autophagy contributes to the chemo-resistance of non-small cell lung cancer in hypoxic conditions. Respir Res 16: 138, 2015.

21. Pedrosa P, Corvo ML, Ferreira-Silva M, Martins P, Carvalheiro MC Costa PM, Martins C, Martins LMDRS, Baptista PV and Fernandes AR: Targeting cancer resistance via multifunctional gold nanoparticles. Int J Mol Sci 20: E5510, 2019.

22. Wu T, Wang MC, Jing L, Liu ZY, Guo H, Liu Y, Bai YY, Cheng YZ, Nan KJ and Liang X: Autophagy facilitates lung adenocarcinoma resistance to cisplatin treatment by activation of AMPK/mTOR signaling pathway. Drug Des Devel Ther 9: 6421-6431, 2015 .
23. Sugita S, Ito K, Yamashiro Y, Moriya S, Che XF, Yokoyama T, Hiramoto $\mathrm{M}$ and Miyazawa K: EGFR-independent autophagy induction with gefitinib and enhancement of its cytotoxic effect by targeting autophagy with clarithromycin in non-small cell lung cancer cells. Biochem Biophys Res Commun 461: 28-34, 2015.

24. Tang MC, Wu MY, Hwang MH, Chang YT, Huang HJ, Lin AM and Yang JC: Chloroquine enhances gefitinib cytotoxicity in gefitinib-resistant nonsmall cell lung cancer cells. PLoS One 10: e0119135, 2015.

25. Sui X, Kong N, Zhu M, Wang X, Lou F, Han W and Pan H: Cotargeting EGFR and autophagy signaling: A novel therapeutic strategy for non-small-cell lung cancer. Mol Clin Oncol 2: 8-12, 2014.

26. Chang CY, Kuan YH, Ou YC, Li JR, Wu CC, Pan PH, Chen WY, Huang HY and Chen CJ: Autophagy contributes to gefitinib-induced glioma cell growth inhibition. Exp Cell Res 327: 102-112, 2014.

27. Cheng Y, Li H, Ren X, Niu T, Hait WN and Yang J: Cytoprotective effect of the elongation factor-2 kinase-mediated autophagy in breast cancer cells subjected to growth factor inhibition. PLoS One 5: e9715, 2010.

28. Pietrocola F, Izzo V, Niso-Santano M, Vacchelli E, Galluzzi L, Maiuri MC and Kroemer G: Regulation of autophagy by stress-responsive transcription factors. Semin Cancer Biol 23: 310-322, 2013.

29. Klionsky DJ, Abeliovich H, Agostinis P, Agrawal DK, Aliev G, Askew DS, Baba M, Baehrecke EH, Bahr BA, Ballabio A, et al: Guidelines for the use and interpretation of assays for monitoring autophagy in higher eukaryotes. Autophagy 4: 151-175, 2008.

30. Varbiro G, Veres B, Gallyas F Jr and Sumegi B: Direct effect of Taxol on free radical formation and mitochondrial permeability transition. Free Radic Biol Med 31: 548-558, 2001.

31. Fulda S, Galluzzi L and Kroemer G: Targeting mitochondria for cancer therapy. Nat Rev Drug Discov 9: 447-464, 2010.

32. Namba T, Takabatake Y, Kimura T, Takahashi A, Yamamoto T, Matsuda J, Kitamura H, Niimura F, Matsusaka T, Iwatani H, et al: Autophagic clearance of mitochondria in the kidney copes with metabolic acidosis. J Am Soc Nephrol 25: 2254-2266, 2014.

33. Randow F and Youle RJ: Self and nonself: How autophagy targets mitochondria and bacteria. Cell Host Microbe 15: 403-411, 2014.

34. Boyer-Guittaut M, Poillet L, Liang Q, Bole-Richard E, Ouyang X, Benavides GA, Chakrama FZ, Fraichard A, Darley-Usmar VM, Despouy G, et al: The role of GABARAPL1/GEC1 in autophagic flux and mitochondrial quality control in MDA-MB-436 breast cancer cells. Autophagy 10: 986-1003, 2014.

35. Karsli-Uzunbas G, Guo JY, Price S, Teng X, Laddha SV, Khor S, Kalaany NY, Jacks T, Chan CS, Rabinowitz JD and White E: Autophagy is required for glucose homeostasis and lung tumor maintenance. Cancer Discov 4: 914-927, 2014.

36. Guo JY, Xia B and White E: Autophagy-mediated tumor promotion. Cell 155: 1216-1219, 2013

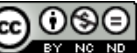

This work is licensed under a Creative Commons Attribution-NonCommercial-NoDerivatives 4.0 International (CC BY-NC-ND 4.0) License. 